\title{
Beyond public reporting
}

\author{
David M. Shahian, MD
}

\footnotetext{
From the Department of Surgery and Center for Quality and Safety, Massachusetts General Hospital, Harvard Medical School, Boston, Mass.

Disclosures: Author has nothing to disclose with regard to commercial support.

Received for publication Feb 16, 2017; accepted for publication Feb 28, 2017; available ahead of print March 23, 2017.

Address for reprints: David M. Shahian, MD, Massachusetts General Hospital, Bulfinch 282, 55 Fruit St, Boston,

MA 02114 (E-mail: dshahian@partners.org).

J Thorac Cardiovasc Surg 2017; 153:1627-9

$0022-5223 / \$ 36.00$

Copyright (C) 2017 by The American Association for Thoracic Surgery

http://dx.doi.org/10.1016/j.jtcvs.2017.02.036
}

The scope of Dr Moffatt-Bruce's essay _ _ "Public Reporting: Will This Help Inform What Patients and Families Need to Know?"- - is considerably more expansive than its title would suggest. Her remarks transcend the usual boundaries of "public reporting" and would more aptly be described as a commentary on the broad topic of health care transparency. Woven throughout her article are 4 challenging transparency issues, each the subject of robust health policy debate.

\section{THE HAZARDS OF TRANSPARENCY WITHOUT STANDARDS}

Public reporting was introduced to facilitate autonomous patient decision making, redirect market share to better providers, and drive performance improvement. ${ }^{2,3}$ Although some states (eg, New York, Massachusetts) and specialties (cardiothoracic surgery) have demonstrated the potential benefits of public reporting, other recent developments are less salutary. The chaotic proliferation of public report cards, many produced by commercial or "public service" rating organizations, has often confused rather than aided patients in selecting providers. Widely divergent, sometimes completely opposite ratings have been produced by different raters for the same provider, ${ }^{4-9}$ producing a distressing cognitive dissonance.

How can different rating organizations arrive at such different conclusions? In some instances, the ratings may simply be measuring different quality constructs. ${ }^{8}$ But there is a much more insidious problem that accounts for many instances of report card inconsistencies. Despite their methodological complexity and far-reaching implications, there are no nationally mandated standards for risk models and performance measures. Methodologies are often opaque or patently flawed, yet report card publication requires neither objective external review nor endorsement. Erroneous results may misdirect patients, falsely impugn or boost reputations, misallocate scarce hospital qualityimprovement resources, and unfairly penalize or reward provider payments. ${ }^{10,11}$ The National Quality Forum (NQF) offers a highly robust measure vetting process, but specialty society).

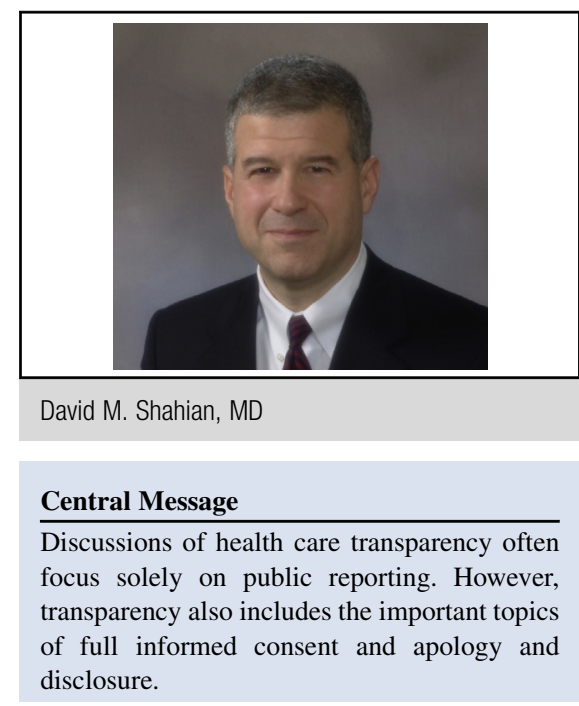

See Article page 1623.

submission of measures to the NQF is voluntary and often not used by report card developers.

Fortunately, in cardiothoracic surgery we have an expanding portfolio of gold-standard measures developed by the Society of Thoracic Surgeons (STS) Quality Measurement Task Force, and these provide trustworthy results for our specialty. ${ }^{12-18}$ The STS measures are based on audited clinical data from the STS National Database. They are collaboratively developed by surgeons and statisticians, published in peer-reviewed journals, and submitted to the NQF for review (where the STS has the largest number of NQF-endorsed performance metrics [33 in 2017] of any

\section{TRANSPARENCY AND THE INDIVIDUAL SURGEON}

Most public report cards, including those produced by the STS, have historically focused on performance at the hospital or program level. Individual physician or surgeon performance is even more challenging than hospital performance to reliably estimate because of smaller sample sizes. ${ }^{19-21}$ However, available data do suggest substantial betweensurgeon variability in outcomes for some procedures, including coronary artery bypass grafting, $^{22,23}$ and patients increasingly demand access to this information. Unfortunately, some highly publicized attempts to produce surgeon-level reports have used manifestly inappropriate methodologies. $^{24-26}$ 
In response to these analytic and health policy concerns, the STS has developed a multidimensional, multiprocedural, multiyear individual surgeon composite measure ${ }^{27}$ with high reliability $(0.81)$, which will soon be available for confidential feedback to surgeons. Only with such highly accurate measures can surgeons refute less credible report card ratings and provide meaningful performance information to patients.

\section{TRANSPARENT INFORMED SURGICAL CONSENT}

Informed surgical consent requires the disclosure of all information that would affect a reasonable person's decision regarding surgery. ${ }^{28-30}$ But in the age of transparency, how expansively should that requirement be interpreted? Consider this thought experiment: What questions might a concerned physician ask if their spouse or child needed a complex procedure in a specialty other than their own, and they were evaluating potential hospitals and surgeons with whom they were not familiar? For example, how many of these procedures are done at your hospital, and how many have you personally performed? What are your results? Will residents be involved in the operation, and to what extent? ${ }^{31}$ What is the hospital's policy, and your practice, regarding concurrent or overlapping surgery ? $^{32-34}$

Many patients and families would not even know to ask such questions or would be embarrassed to do so, yet they would certainly be relevant to most "reasonable" patients envisioned by informed consent standards. Arguably, then, is it the surgeon's responsibility to proactively address these issues to achieve truly informed consent?

\section{TRANSPARENCY, APOLOGY, AND DISCLOSURE}

Finally, what happens when adverse events occur as the result of provider error or systems issues, rather than the inherent risk of a patient's disease or treatment? There is increasing recognition that physicians have an ethical and professional responsibility to disclose such events to patients. ${ }^{35-38}$ This includes a full and understandable explanation of what happened, acknowledgment of responsibility, apology, a plan to prevent recurrences, and negotiated financial reparations when appropriate. Fear of litigation or loss of reputation may discourage some practitioners from robust disclosure and apology, although data suggest these may be unwarranted concerns. However, irrespective of the consequences, providers must discuss these issues honestly and thoroughly with their patients. Many will find this a cathartic experience, as they too have been suffering as the "second victim."

\section{CONCLUSIONS}

All 4 of the issues mentioned by Dr Moffatt-Bruce ${ }^{1}$ have a common theme: Transparency is a fundamental ethical mandate in health care. Physicians who embrace this principle will strengthen, not jeopardize, the sacred bond they share with their patients.

\section{References}

1. Moffatt-Bruce S. Public reporting: will this help inform what patients and families need to know? J Thorac Cardiovasc Surg. 2017;153:1623-6.

2. Shahian DM, Edwards FH, Jacobs JP, Prager RL, Normand SL, Shewan CM, et al. Public reporting of cardiac surgery performance: part 1-history, rationale, consequences. Ann Thorac Surg. 2011;92(3 Suppl):S2-11.

3. Shahian DM, Edwards FH, Jacobs JP, Prager RL, Normand SL, Shewan CM, et al. Public reporting of cardiac surgery performance: part 2-implementation. Ann Thorac Surg. 2011;92(3 Suppl):S12-23.

4. Healthcare Association of New York State. HANY's report on report cards: understanding publicly reported hospital quality measures. 2013. Available at: http://www.hanys.org/quality/data/report_cards/2013/docs/2013_hanys_report_ card_book.pdf. Accessed February 5, 2014.

5. Berenson RA, Pronovost PJ, Krumholz HM. Achieving the potential of health care performance measures. 2013. Available at: http://www.rwjf.org/content/ dam/farm/reports/reports/2013/rwjf406195. Accessed February 5, 2014.

6. Leonardi MJ, McGory ML, Ko CY. Publicly available hospital comparison web sites: determination of useful, valid, and appropriate information for comparing surgical quality. Arch Surg. 2007;142:863-8.

7. Hwang W, Derk J, LaClair M, Paz H. Finding order in chaos: a review of hospital ratings. Am J Med Qual. 2016;31:147-55.

8. Austin JM, Jha AK, Romano PS, Singer SJ, Vogus TJ, Wachter RM, et al. National hospital ratings systems share few common scores and may generate confusion instead of clarity. Health Aff (Millwood). 2015;34:423-30.

9. Rothberg MB, Morsi E, Benjamin EM, Pekow PS, Lindenauer PK. Choosing the best hospital: the limitations of public quality reporting. Health Aff (Millwood). 2008;27:1680-7.

10. Shahian DM, Normand SL, Friedberg MW, Hutter MM, Pronovost PJ. Rating the raters: the inconsistent quality of health care performance measurement. Ann Surg. 2016;264:36-8.

11. Shahian DM, Mort EA, Pronovost PJ. The quality measurement crisis: an urgent need for methodological standards and transparency. Jt Comm J Qual Patient Saf. 2016;42:435-8.

12. Shahian DM, Edwards FH, Ferraris VA, Haan CK, Rich JB, Normand SL, et al. Quality measurement in adult cardiac surgery: part 1-Conceptual framework and measure selection. Ann Thorac Surg. 2007;83(4 Suppl):S3-12.

13. O'Brien SM, Shahian DM, Delong ER, Normand SL, Edwards FH, Ferraris VA, et al. Quality measurement in adult cardiac surgery: part 2-Statistical considerations in composite measure scoring and provider rating. Ann Thorac Surg. 2007; 83(4 Suppl):S13-26.

14. Shahian DM, He X, Jacobs JP, Rankin JS, Welke KF, Filardo G, et al. The Society of Thoracic Surgeons Isolated Aortic Valve Replacement (AVR) composite score: a report of the STS Quality Measurement Task Force. Ann Thorac Surg. 2012;94:2166-71.

15. Shahian DM, He X, Jacobs JP, Rankin JS, Welke KF, Edwards FH, et al. The STS AVR + CABG composite score: a report of the STS Quality Measurement Task Force. Ann Thorac Surg. 2014;97:1604-9.

16. Badhwar V, Rankin JS, He X, Jacobs JP, Gammie JS, Furnary AP, et al. The Society of Thoracic Surgeons mitral repair/replacement composite score: a report of the Society of Thoracic Surgeons Quality Measurement Task Force. Ann Thorac Surg. 2016;101:2265-71.

17. Rankin JS, Badhwar V, He X, Jacobs JP, Gammie JS, Furnary AP, et al. The Society of Thoracic Surgeons mitral valve repair/replacement plus coronary artery bypass grafting composite score: a report of the Society of Thoracic Surgeons Quality Measurement Task Force. Ann Thorac Surg. December 6, 2016 [Epub ahead of print].

18. Kozower BD, O’Brien SM, Kosinski AS, Magee MJ, Dokholyan R, Jacobs JP, et al. The Society of Thoracic Surgeons composite score for rating program performance for lobectomy for lung cancer. Ann Thorac Surg. 2016;101: 1379-87.

19. Austin PC, Reeves MJ. Effect of provider volume on the accuracy of hospital report cards: a Monte Carlo study. Circ Cardiovasc Qual Outcomes. 2014;7:299-305.

20. Krell RW, Hozain A, Kao LS, Dimick JB. Reliability of risk-adjusted outcomes for profiling hospital surgical quality. JAMA Surg. 2014;149:467-74.

21. Hofer TP, Hayward RA, Greenfield S, Wagner EH, Kaplan SH, Manning WG. The unreliability of individual physician "report cards" for assessing the costs and quality of care of a chronic disease. JAMA. 1999;281:2098-105. 
22. Wu C, Hannan EL, Ryan TJ, Bennett E, Culliford AT, Gold JP, et al. Is the impact of hospital and surgeon volumes on the in-hospital mortality rate for coronary artery bypass graft surgery limited to patients at high risk? Circulation. 2004;110: 784-9.

23. Hannan EL, Wu C, Ryan TJ, Bennett E, Culliford AT, Gold JP, et al. Do hospitals and surgeons with higher coronary artery bypass graft surgery volumes still have lower risk-adjusted mortality rates? Circulation. 2003; 108:795-801.

24. ProPublica. Surgeon scorecard. Available at: https://projects.propublica.org/ surgeons/. Accessed September 23, 2015.

25. Ban KA, Cohen ME, Ko CY, Friedberg MW, Stulberg JJ, Zhou L, et al. Evaluation of the ProPublica Surgeon Scorecard "Adjusted Complication Rate" measure specifications. Ann Surg. 2016;264:566-74.

26. Friedberg MW, Pronovost PJ, Shahian DM, Safran DG, Bilimoria KY, Elliott $\mathrm{MN}$, et al. A methodological critique of the ProPublica Surgeon Scorecard. Santa Monica, CA: RAND Corporation; September 25, 2015. Available at: http://www.rand.org/pubs/perspectives/PE170.html. Accessed February 9, 2017.

27. Shahian DM, He X, Jacobs JP, Kurlansky PA, Badhwar V, Cleveland JC Jr, et al. The Society of Thoracic Surgeons composite measure of individual surgeon performance for adult cardiac surgery: a report of the Society of Thoracic Surgeons Quality Measurement Task Force. Ann Thorac Surg. 2015;100:1315-25.

28. Childers R, Lipsett PA, Pawlik TM. Informed consent and the surgeon. J Am Coll Surg. 2009;208:627-34.
29. Clarke S, Oakley J. Informed Consent and Clinician Accountability: The Ethic: of Report Cards on Surgeon Performance. Cambridge: Cambridge University Press; 2007

30. Jones JW, McCullough LB, Richman BW. A comprehensive primer of surgical informed consent. Surg Clin North Am. 2007;87:903-18.

31. McAlister C. Breaking the silence of the switch-increasing transparency about trainee participation in surgery. N Engl J Med. 2015;372:2477-9.

32. Hoyt DB. Overlapping surgery: safety data and ongoing concerns. Ann Surg. 2017;265:645-6.

33. Langerman A. Concurrent surgery and informed consent. JAMA Surg. 2016;151: 601-2.

34. Abelson J, Saltzman J, Kowalczyk L, Allen S. Clash in the name of care. Boston Globe. October 25, 2015. Available at: https://apps.bostonglobe.com/spotlight/ clash-in-the-name-of-care/story/. Accessed March 20, 2017.

35. Massachusetts Coalition for the Prevention of Medical Errors. When things go wrong: responding to adverse events. 2006. Available at: http://www macoalition.org/documents/respondingToAdverseEvents.pdf. Accessed February 9, 2017.

36. Levinson W, Yeung J, Ginsburg S. Disclosure of medical error. JAMA. 2016;316: 764-5.

37. Vincent C. Understanding and responding to adverse events. N Engl J Med. 2003 348:1051-6.

38. Kachalia A, Kaufman SR, Boothman R, Anderson S, Welch K, Saint S, et al. Liability claims and costs before and after implementation of a medical error disclosure program. Ann Intern Med. 2010;153:213-21. 